\title{
Chylopericardium in adults: A literature review over the past decade (1996-2006)
}

\author{
Chadi Dib, MD, A. Jamil Tajik, MD, Soon Park, MD, Mohammed E. L. Kheir, MD, Bijoy Khandieria, MD, and \\ Farouk Mookadam, MD, MSc
}

From the Mayo Clinic College of Medicine, Division of Cardiovascular Diseases and Cardiovascular Surgery, Scottsdale, Ariz.

Received for publication Aug 28, 2007; revisions received Feb 18, 2008; accepted for publication March 30, 2008.

Address for references: Farouk Mookadam, MD, FRCPC, FACC, MSc, 13400 E Shea Blvd, Scottsdale, AZ 85259 (E-mail: mookadam.farouk@mayo.edu).

J Thorac Cardiovasc Surg 2008;136:650-6 $0022-5223 / \$ 34.00$

Copyright (C) 2008 by The American Association for Thoracic Surgery

doi:10.1016/j.jtcvs.2008.03.033
Objectives: We present a systematic overview of the literature on reported cases of chylous pericardial effusion in adults over the past 10 years, assessing clinical presentation, etiology, diagnosis, and treatment.

Methods: We conducted an evidence-based literature review searching for all reported adult cases of chylopericardium in the past 10 years (January 1996-December 2006).

Results: A total of 33 reported cases of chylopericardium were identified through a systematic literature search. There was no gender bias in the incidence of chylous pericardial effusion. Age at diagnosis varied from 18 to 68 years with a mean \pm standard deviation of $36.78 \pm 14.71$ years. Time from symptom onset to diagnosis was variable (ranging from acute presentation to several years).The most common reported etiology was idiopathic. The diagnosis was made by pericardiocentesis in all patients. A search for secondary causes included computed tomography of the chest, lymphoscintigraphy, and lymphangiography along with radioactive oral ${ }^{131}$ I-triolein. Conservative therapy was prescribed in 28 patients and failed in 16 , in whom subsequent surgery was necessary. Overall, 21 patients underwent various types of surgery. Thoracic duct ligation with creation of a pericardial window was the most common surgical procedure.

Conclusion: Chylopericardium is a rare entity. The fluid appearance, triglyceride content, cytologic characteristics, and negative cultures are crucial to make the correct diagnosis. Treatment is dependent on the etiology. Surgical management is the most successful. Conservative therapy is reserved for patients with idiopathic chylopericardium, those with an untreatable etiology, those considered at high risk for surgical treatment, or those with a predictably short lifespan.

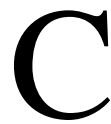
hylopericardium is a rare entity in which chylous fluid containing triglycerides in high concentrations accumulates in the pericardial cavity. It was first described by Hasebrock in $1888^{1}$ and subsequently reviewed in $1935,{ }^{2}$ with 3 cases of chylopericardium being identified among 100 cases of nontraumatic chylothorax. ${ }^{1}$ The etiology of chylopericardium includes congenital mediastinal lymphangiectasia, ${ }^{3}$ iatrogenic after cardiac surgery, ${ }^{4-6}$ gastric signet ring cell carcinoma, ${ }^{7}$ Gorham syndrome (osteolysis that results from lymphangiomatosis with adjacent bone resorption), ${ }^{8}$ malignant tumors (eg, mediastinal tumors including mediastinal dysgerminomas $^{9}$ ), blunt or penetrating trauma, infection, radiation, congenital lymphatic anomalies, ${ }^{6}$ or primary idiopathic. ${ }^{10-15}$ There is no evidence-based systematic overview on the topic in the past decade. Diagnosis can be challenging and optimal treatment of chylopericardium remains controversial.

\section{Methods}

A computerized Ovid and MEDLINE database search (from January 1, 1996, until December 31, 2006) was undertaken to identify English and French articles describing chylopericardium. Search terms included the following: "chylopericardium," "chylous pericardial effusion," and the combined term "chylopericardium and 


\section{Abbreviations and Acronyms}

VATS $=$ video-assisted thoracoscopic surgery

pericardial effusion" without limits. We identified 70 articles on the basis of a priori inclusion criteria ${ }^{16}: 29$ were deemed relevant for inclusion in this study (ie, adult patients $>18$ years of age with a confirmed diagnosis of chylous pericardial effusion). A second search using the EMBASE database (from January 1996 until December 1, 2006) was undertaken using similar search terms and revealed two additional articles. $^{17,18}$ In addition, a qualified librarian independently completed a MEDLINE, Ovid, and EMBASE search and identified no new articles. The reference section of all articles was scanned for further articles and no new cases were identified beyond the electronic search. All relevant articles were independently reviewed and analyzed by two of the authors (F.M. and C.D.). Thirty-three cases were identified from 31 articles. Patient demographics, clinical presentation, diagnosis, and treatment were identified for each of the cases (Table 1).

\section{Statistical Analysis}

Means and standard deviations were used for categorical variables (Table 1). A formal Kappa test of heterogeneity was not performed inasmuch as the articles were from different continents, spanned a decade, and were sufficiently different to preclude the necessity of formal Kappa testing.

\section{Results}

There was no gender bias in disease occurrence: $16(48 \%)$ female and $17(52 \%)$ male (Table 1). Age at diagnosis ranged from 18 to 68 years with a mean \pm standard deviation of $36.78 \pm 14.71$ years. Time from onset of symptoms to diagnosis showed wide variation ranging from several years (13 years $^{19}$ in a patient who was incidentally discovered to have an enlarged heart and remained asymptomatic and 12 years ${ }^{15}$ in a patient whose condition also was discovered incidentally and who refused pericardiocentesis) to acute presentations with tamponade. ${ }^{20,21}$ The commonest causes of chylopericardium over the past decade were as follows: idiopathic $(56 \%),{ }^{3,10-15,19,20,22-31}$ postoperative (9\%) (viz, mitral valve replacement $[6 \%],{ }^{1,4}$ coronary artery surgery $[3 \%],{ }^{5}$ and orthotopic heart transplantation $[3 \%]^{6}$ ), malignant disease of the lymphatic system or other mediastinal neoplasms $(6 \%)$ including mediastinal lymphangioma $(3 \%)^{32}$ and mediastinal dysgerminoma $(3 \%),{ }^{9}$ signet ring cell carcinoma $(3 \%),{ }^{7}$ Gorham syndrome $(3 \%),{ }^{8}$ blunt trauma $(3 \%),{ }^{28}$ mediastinal lymphangiectasis $(3 \%),{ }^{3}$ vein thrombosis $(3 \%),{ }^{17}$ endovascular treatment of superior vena cava syndrome $(3 \%),{ }^{33}$ and tuberculosis (3\%). ${ }^{34}$ Abnormalities of the lymphatic system $^{22}$ and mediastinal lymphangiectasis ${ }^{3}$ causing chyloperi- cardial effusions were referred to as idiopathic causes. The commonest presentation for patients with chylopericardium was dyspnea $(64 \%)$, including patients with tamponade $(33 \%)^{1,5,6,17,18,21-23,32,37}$ and patients with chest pain or discomfort (12\%). ${ }^{9,9,18,20}$ Two $(6 \%)$ patients presented with syncope, ${ }^{14,23}$ and chylopericardium was diagnosed later.

Diagnosis is usually established after pericardiocentesis with meticulous fluid analysis, emphasizing fluid color and triglyceride content (Table 2). Four patients had low pericardial fluid triglyceride levels ${ }^{4,7,20}(181 \mathrm{mg} / \mathrm{dL}, 216 \mathrm{mg} / \mathrm{dL}$, $245 \mathrm{mg} / \mathrm{dL}$, and $197 \mathrm{mg} / \mathrm{dL}$ ) and still had a diagnosis of chylous pericardial effusion. All other patients had a triglyceride level in the pericardial fluid of more than $500 \mathrm{mg} / \mathrm{dL}$ with the highest being $2546 \mathrm{mg} / \mathrm{dL}^{22}$ Characteristics of the pericardial fluid analysis are summarized in Table 2 . There are no unique features on echocardiogram, chest x-ray film, or electrocardiogram that could predict the diagnosis of chylous pericardial effusion.

\section{Treatment}

Conservative management was prescribed in $28(84.84 \%)$ patients and consisted of pericardiocentesis alone $(27 \%),{ }^{12,19,20,25,28,29,33}$ pericardiocentesis followed by medium chain triglycerides diet $(6 \%)^{23,34}$ and total parenteral nutrition $(12 \%),{ }^{1,6,22,24}$ pericardiocentesis followed by total parenteral nutrition and external beam radiation $(3 \%),{ }^{8}$ pericardiocentesis only followed by total parenteral nutrition $(6 \%),{ }^{5,17}$ pericardiocentesis followed by vena caval revascularization $(3 \%),{ }^{33}$ and diagnostic nontherapeutic pericardiocentesis followed by total parenteral nutrition $(9 \%), 4,9,21$ low fat diet $(6 \%),{ }^{7,18}$ or medium chain triglyceride diet $(9 \%) .^{3,14,26}$ In one patient conservative therapy was not described $(3 \%) .^{10}$

Surgery was performed in 21 patients $(57.57 \%)$, consisting of open thoracotomy in 7 patients $(33.33 \%)^{9,11,12,15,17,18,21,31}$ or video-assisted thoracoscopic surgery (VATS) in 10 patients $(47.6 \%)^{6,10,13,22,25,28-30,32}$ with subsequent thoracic duct ligation and creation of a pericardial window. One case $(4.7 \%)^{19}$ consisted of thoracotomy and laparotomy with lymphovenous anastomosis between the thoracic duct and left renal vein. Another case $(4.7 \%)$ consisted of pleuropericardial window and tumor resection. ${ }^{9}$ There have been 2 case reports of chylopericardium in which the type of surgery (VATS vs open thoracotomy) was not defined $(10.5 \%){ }^{14,23}$

Conservative treatment failed in 16 of 28 cases $(57.1 \%){ }^{\dagger}$ Time period from diagnosis to surgical treatment varied from 2 days $^{21}$ to 4 years $^{28}$ with a mean of 150 days.

Follow-up was reported in 29 of the cases and ranged from 1 month $^{29}$ to 108 months $^{3}$ with a mean of 16 months. Four

\footnotetext{
* References 1, 5-10, 14, 17-22, 26, 29-33, 35, 36.

${ }^{\dagger}$ References 6, 9, 10, 12, 14, 17-19, 21-23, 25, 27-31.
} 
TABLE 1. General characteristics of studies meeting inclusion criteria

\begin{tabular}{|c|c|c|c|c|c|c|c|c|}
\hline $\begin{array}{l}\text { Case } \\
\text { report }\end{array}$ & $\begin{array}{c}\text { Year of } \\
\text { publication }\end{array}$ & $\begin{array}{c}\text { Age at } \\
\text { diagnosis/ } \\
\text { sex }\end{array}$ & $\begin{array}{l}\text { Symptoms at } \\
\text { presentation }\end{array}$ & Cause & $\begin{array}{c}\text { Conservative } \\
\text { treatment }\end{array}$ & $\begin{array}{l}\text { Surgical } \\
\text { treatment }\end{array}$ & Complications & $\begin{array}{l}\text { Follow- } \\
\text { up }\end{array}$ \\
\hline $\begin{array}{l}\text { Yokusoglu } \\
\mathrm{M}^{11}\end{array}$ & 2005 & $36 / \mathrm{M}$ & Asymptomatic & Idiopathic & No & $\begin{array}{l}\text { Yes: open } \\
\text { thoracotomy }\end{array}$ & No & $3 \mathrm{~m}$ \\
\hline Zisis $\mathrm{C}^{21}$ & 2005 & $25 / M$ & Tamponade & $\begin{array}{l}\text { Lymphangiomatous } \\
\text { hamartoma? }\end{array}$ & Yes: TPN & $\begin{array}{l}\text { Yes: open } \\
\text { thoracotomy }\end{array}$ & No & $12 \mathrm{~m}$ \\
\hline Pop D 32 & 2005 & $60 / \mathrm{M}$ & Tamponade & $\begin{array}{l}\text { Mediastinal } \\
\text { lymphangioma }\end{array}$ & No & Yes $\ddagger$ & No & $15 \mathrm{~m}$ \\
\hline Cho $\mathrm{BC}^{24}$ & 2005 & $43 / \mathrm{F}$ & Asymptomatic & Idiopathic & $\begin{array}{l}\text { Yes: } \\
\text { pericardiocentesis, } \\
\text { MTC diet, TPN, } \\
\text { pericardiostomy }\end{array}$ & No & No & $6 \mathrm{~m}$ \\
\hline Mitsui $K^{22}$ & 2005 & $27 / F$ & SOB on exertion & Idiopathic & $\begin{array}{l}\text { Yes: } \\
\text { pericardiocentesis, } \\
\text { MTC diet, TPN }\end{array}$ & Yes: VATS & No & $41 \mathrm{~m}$ \\
\hline \multirow[t]{2}{*}{ Nanjo $S^{20}$} & 2004 & $47 / M$ & $\mathrm{CP}, \mathrm{SOB}$ & Idiopathic & $\begin{array}{l}\text { Yes: } \\
\quad \text { pericardiocentesis }\end{array}$ & No & No & NA \\
\hline & & $21 / F$ & SOB & Idiopathic & $\begin{array}{l}\text { Yes: } \\
\text { pericardiocentesis, } \\
\text { pericardiostomy }\end{array}$ & & & \\
\hline Pitol $R^{1}$ & 2004 & $24 / F$ & Tamponade & MVR & $\begin{array}{l}\text { Yes: } \\
\text { pericardiocentesis, } \\
\text { MTC diet, TPN }\end{array}$ & No & No & NA \\
\hline Sasaki $A^{4}$ & 2002 & 49/M & Asymptomatic & MVR & $\begin{array}{l}\text { Yes: TPN, } \\
\text { pericardiostomy }\end{array}$ & No & No & $3 \mathrm{~m}$ \\
\hline Yoshioka $\mathrm{H}^{25}$ & 2003 & 28/M & Asymptomatic & Idiopathic & $\begin{array}{l}\text { Yes: } \\
\quad \text { pericardiocentesis }\end{array}$ & $\begin{array}{l}\text { Yes: VATS, } \\
12 \text { years later }\end{array}$ & $\begin{array}{l}\text { Salmonella } \\
\text { pericarditis } \\
12 \text { years } \\
\text { later }\end{array}$ & $11 \mathrm{~m}$ \\
\hline Sleilaty $\mathrm{G}^{15}$ & 2002 & $68 / F$ & Asymptomatic & Idiopathic & No & $\begin{array}{l}\text { Yes: open } \\
\text { thoracotomy }\end{array}$ & No & $12 \mathrm{~m}$ \\
\hline Chen $\mathrm{FC}^{26}$ & 2003 & $65 / F$ & SOB on exertion & Idiopathic & Yes: MTC diet & No & No & $\begin{array}{l}3 \mathrm{~m} \text { : } \\
\quad \text { residual } \\
\text { PE }\end{array}$ \\
\hline Mahon $\mathrm{NG}^{12}$ & 2003 & $25 / M$ & Asymptomatic & Idiopathic & $\begin{array}{l}\text { Yes: } \\
\quad \text { pericardiocentesis }\end{array}$ & $\begin{array}{l}\text { Yes: open } \\
\text { thoracotomy }\end{array}$ & No & $18 \mathrm{~m}$ \\
\hline Swelstad MR ${ }^{8}$ & 2003 & $31 / \mathrm{F}$ & Tamponade & $\begin{array}{l}\text { Gorham's } \\
\text { syndrome }\end{array}$ & $\begin{array}{l}\text { Yes: } \\
\text { pericardiocentesis, } \\
\text { TPN, external } \\
\text { beam radiation }\end{array}$ & No & $\begin{array}{l}\text { Radiation } \\
\text { pneumonitis }\end{array}$ & NA \\
\hline Watanabe $\mathrm{S}^{10}$ & 2002 & $30 / F$ & Tamponade & Idiopathic & Yes (NA) & Yes: VATS & No & $6 \mathrm{~m}$ \\
\hline Gelsomino $S^{6}$ & 2002 & $40 / \mathrm{F}$ & $\begin{array}{l}\text { CP, SOB, LLE, } \\
\text { then } \\
\text { tamponade }\end{array}$ & $\begin{array}{l}\text { Orthotopic heart } \\
\text { transplantation }\end{array}$ & $\begin{array}{l}\text { Yes: } \\
\text { pericardiocentesis, } \\
\text { TPN, MTC diet }\end{array}$ & Yes: VATS & No & $3 \mathrm{~m}$ \\
\hline \multirow[t]{2}{*}{ Wurnig $\mathrm{PN}^{28}$} & 2000 & $18 / \mathrm{F}$ & NA & Trauma & $\begin{array}{l}\text { Yes: } \\
\quad \text { pericardiocentesis }\end{array}$ & Yes: VATS & No & $24 \mathrm{~m}$ \\
\hline & & $42 / F$ & NA & NA & No & Yes: VATS & & $7 \mathrm{~m}$ \\
\hline Sakata $S^{13}$ & 2000 & $20 / M$ & Asymptomatic & Idiopathic & No & Yes: VATS & No & $12 \mathrm{~m}$ \\
\hline Wang $\mathrm{CH}^{14}$ & 2000 & $61 / M$ & $\begin{array}{l}\text { Syncope, SOB, } \\
\text { SOB } \\
\text { on exertion }\end{array}$ & Idiopathic & $\begin{array}{l}\text { Yes } \\
\text { pericardiostomy, } \\
\text { MTC diet }\end{array}$ & Yes & No & $4 \mathrm{~m}$ \\
\hline Sharpe $D A^{5}$ & 1999 & $63 / F$ & Tamponade & $\begin{array}{l}\text { Coronary artery } \\
\text { Surgery }\end{array}$ & $\begin{array}{l}\text { Yes: } \\
\text { pericardiocentesis, } \\
\text { pericardiostomy, } \\
\text { TPN }\end{array}$ & No & No & $18 \mathrm{~m}$ \\
\hline Mogulkoc $\mathrm{N}^{7}$ & 1999 & $19 / F$ & $\begin{array}{r}\text { SOB, fatigue, } \\
\text { dry cough }\end{array}$ & $\begin{array}{l}\text { Signet ring cell } \\
\text { carcinoma }\end{array}$ & Yes: low fat diet & No & $\begin{array}{c}\text { Death after } \\
3.5 \mathrm{~m}\end{array}$ & Death \\
\hline
\end{tabular}


TABLE 1. Continued

\begin{tabular}{|c|c|c|c|c|c|c|c|c|}
\hline $\begin{array}{l}\text { Case } \\
\text { report }\end{array}$ & $\begin{array}{c}\text { Year of } \\
\text { publication }\end{array}$ & $\begin{array}{c}\text { Age at } \\
\text { diagnosis/ } \\
\text { sex }\end{array}$ & $\begin{array}{l}\text { Symptoms at } \\
\text { presentation }\end{array}$ & Cause & $\begin{array}{c}\text { Conservative } \\
\text { treatment }\end{array}$ & $\begin{array}{l}\text { Surgical } \\
\text { treatment }\end{array}$ & Complications & $\begin{array}{l}\text { Follow- } \\
\text { up }\end{array}$ \\
\hline $\begin{array}{l}\text { Andrade } \\
\quad \text { Santiago } \mathrm{J}^{9}\end{array}$ & 1998 & $30 / \mathrm{M}$ & $\mathrm{CP}, \mathrm{SOB}$ & $\begin{array}{l}\text { Mediastinal } \\
\text { dysgerminoma }\end{array}$ & Yes: TPN & Yes: PPW & $\begin{array}{l}\text { Bleeding and } \\
\text { death after } \\
11 \text { days }\end{array}$ & death \\
\hline Chello $\mathrm{M}^{18}$ & 1998 & $33 / F$ & SOB, CP, LLE & $\begin{array}{l}\text { Idiopathic } \\
\text { (previous } \\
\text { infective } \\
\text { endocarditis, } \\
\text { heroin } \\
\text { addiction) }\end{array}$ & Yes: low fat diet & $\begin{array}{l}\text { Yes: open } \\
\text { thoracotomy }\end{array}$ & No & $3 \mathrm{~m}$ \\
\hline Scholten $\mathrm{C}^{19}$ & 1998 & $24 / \mathrm{M}$ & $\begin{array}{l}\text { NA, patient } \\
\text { returned after } \\
13 \text { years with } \\
\text { SOB }\end{array}$ & Idiopathic & $\begin{array}{l}\text { Yes: } \\
\quad \text { pericardiocentesis }\end{array}$ & Yes: T\&L & No & $20 \mathrm{~m}$ \\
\hline Furrer $\mathrm{M}^{29}$ & 1996 & $35 / M$ & $\begin{array}{l}\text { SOB, cough then } \\
\text { tamponade }\end{array}$ & Idiopathic & Yes: pericardiocentesis & Yes: VATS & No & $\begin{array}{l}1 \mathrm{~m}: \\
\quad \text { residua } \\
\text { PE }\end{array}$ \\
\hline Baratella $\mathrm{MC}^{3}$ & 1998 & $26 / \mathrm{M}$ & Asymptomatic & Idiopathic & Yes: MTC diet & No & No & $108 \mathrm{~m}$ \\
\hline Chen $\mathrm{CM}^{17}$ & 2004 & $39 / \mathrm{M}$ & $\begin{array}{l}\text { SOB on } \\
\text { exertion, } \\
\text { tamponade }\end{array}$ & $\begin{array}{l}\text { Thrombosis in } \\
\text { right IJ and } \\
\text { Left SVC }\end{array}$ & $\begin{array}{l}\text { Yes: pericardiocentesis, } \\
\text { TPN }\end{array}$ & $\begin{array}{l}\text { Yes: open } \\
\text { thoracotomy }\end{array}$ & No & NA \\
\hline Veroux $\mathrm{P}^{33}$ & 2002 & $45 / \mathrm{F}$ & Tamponade & SVC syndrome & $\begin{array}{l}\text { Yes: pericardiocentesis, } \\
\text { VCR }\end{array}$ & No & No & NA \\
\hline Mehrotra $S^{23}$ & 2006 & $22 / \mathrm{M}$ & $\begin{array}{l}\text { Syncope, } \\
\text { tamponade }\end{array}$ & Idiopathic & $\begin{array}{l}\text { Yes: pericardiocentesis, } \\
\text { MTC diet }\end{array}$ & Yes (NA) & No & $12 \mathrm{~m}$ \\
\hline Liberman $\mathrm{M}^{30}$ & 2006 & $45 / M$ & Tamponade & Idiopathic & Yes: pericardiocentesis & Yes: VATS & No & $48 \mathrm{~m}$ \\
\hline Svedjeholm $\mathrm{R}^{31}$ & 1997 & $51 \mathrm{~F}$ & SOB & Idiopathic & Yes: pericardiocentesis & $\begin{array}{l}\text { Yes: open } \\
\text { thoracotomy }\end{array}$ & No & $12 \mathrm{~m}$ \\
\hline $\begin{array}{l}\text { Wieshammer } \\
\mathrm{S}^{34}\end{array}$ & 2006 & $22 / \mathrm{M}$ & SOB & Tuberculosis & $\begin{array}{l}\text { Yes: pericardiocentesis, } \\
\text { MTC diet }\end{array}$ & No & No & $9 \mathrm{~m}$ \\
\hline
\end{tabular}

$C P$, Chest pain, heaviness, discomfort, or oppression; $I J$, internal jugular; $L L E$, bilateral lower leg edema; $m$, months, MTC, medium chain triclyceride; $M V R$, mitral valve replacement; $N A$, not available; $P E$, pericardial effusion; $P P W$, pleuropericardial window and tumor resection; $S O B$, shortness of breath; $S V C$, superior vena cava; $T \& L$, thoracotomy and laparotomy for lymphovenous anastomosis; $T P N$, total parenteral nutrition; VCR, vena caval revascularization with local thrombolytic therapy and placement of self-expanding metallic stent. All patients except for one ${ }^{15}$ underwent diagnostic pericardiocentesis. Patients listed in Table 1 as having conservative therapy with pericardiocentesis had either therapeutic or diagnostic tap in the setting of tamponade or else underwent repetitive pericardiocentesis.

papers did not report follow-up. ${ }^{1,17,20,33}$ A small residual pericardial effusion was noted in 2 cases at 3 months and 1 month after surgery. ${ }^{26,29}$ Mortality from chylopericardium was low (only 2 cases, 6\%). One patient died of bleeding 11 days after surgery. ${ }^{7}$ Reports complicated by death were attributed to signet ring cell carcinoma ${ }^{7}$ and mediastinal dysgerminoma. ${ }^{9}$ Among the 18 cases of idiopathic chylous effusion, conservative therapy failed in $11(61 \%)$ and surgery was necessary ${ }^{\ddagger}$; there were no deaths. Two $(11 \%)$ patients were treated surgically ${ }^{13,15}$ and $5(27.7 \%)$ responded to conservative therapy alone.

\section{Discussion}

The accumulation of chyle in the pericardial cavity is rare. Causes are multiple and include trauma, mediastinal neo-

\footnotetext{
${ }^{\ddagger}$ References $10,12,14,18,19,22,23,25,29-31$
}

plasm, thrombosis of the subclavian vein, tuberculosis, thoracic surgery, ${ }^{24}$ Behçet syndrome, ${ }^{35}$ or Gorham syndrome. Primary idiopathic chylopericardium is known to be a less common cause of chylopericardium ${ }^{24}$ but has been reported with increasing frequency in the past 10 years. Given that idiopathic chylous pericardial effusion is rare, it lends itself to the bias of reporting and publication.

Idiopathic chylopericardium is a diagnosis of exclusion and is invoked when no discernible cause is evident. This entity has two possible explanations: (1) the presence of damaged lymphatic vessels with abnormal communication of the thoracic duct to the pericardial lymphatics resulting in chylous reflux or (2) elevated pressure in the thoracic duct, which may occur in lymphangiectasia. ${ }^{24}$

Symptoms at presentation are not indicative of the cause of the pericardial effusion. Some patients remain asymptomatic $c^{3,4,11-13 ; 15,24-26}$ and are noted to have cardiomegaly on routine chest radiograph. Most of the patients 
TABLE 2. Characteristics of chylous fluid analysis

\begin{tabular}{ll}
\hline \multicolumn{1}{c}{ Fluid appearance } & \multicolumn{1}{c}{ Milky yellowish appearance } \\
\hline Triglyceride content & $>500 \mathrm{mg} / \mathrm{dL}$ \\
Cholesterol/triglyceride ratio & $<1.0$ \\
Fluid cultures & Negative cultures \\
Fluid cell count & Lymphocytic predominance
\end{tabular}

who have severe shortness of breath and tamponade ${ }^{1,5,17,21,23,32}$ receive therapeutic and diagnostic pericardiocentesis.

Many diagnostic modalities have been described, including (1) observation of Sudan III dye distribution into the pericardial cavity after oral intake of Sudan III dye, ${ }^{20}$ (2) lymphangioscintigraphy, ${ }^{14,23}$ (3) lymphangiography, ${ }^{19}$ and (4) evaluation of chest radioactivity after an oral dose of ${ }^{131}$ I-triolein. ${ }^{20}$ All of these methods are used to ascertain the cause of the chylous pericardial effusion. Because of the paucity of cases, the sensitivity and specificity of each diagnostic modality is unknown and likely reflects the expertise of the local center. Lymphoscintigraphy appears to be the most commonly used modality. Pericardiocentesis followed by cytology, chemistry, and culture is necessary to definitively make the diagnosis. Analysis of the fluid usually shows a whitish or milky aspirate with a high triglyceride and protein content, a predominance of lymphocytes, and the presence of fat globules by Sudan III staining. Blood cultures are universally negative. There have been a few cases ${ }^{4,7,20}$ in which the triglyceride level was low and the diagnosis of a chylous pericardial effusion was made. This occurs because there is no universally accepted triglyceride level that is required to confirm the diagnosis. There is no doubt in the diagnosis if the pericardial fluid analyses meets the criteria shown in Table 2: a milky yellowish appearance, a triglyceride level greater than $500 \mathrm{mg} / \mathrm{dL}$, a cholesterol/triglyceride ratio less than 1 , and negative cultures with lymphocyte predominance on cytologic examination (one point). A score of 2 (specificity and sensitivity of $100 \%$ ) is required for a diagnosis of chylopericardium.

Optimal treatment of patients with chylopericardium is unclear. Conservative therapy in the absence of hemodynamic compromise is one option. ${ }^{25}$ Rarely, a single pericardiocentesis will prevent recurrence. ${ }^{20}$ Pericardiocentesis followed by pericardiostomy, ${ }^{24}$ a medium chain triglyceride diet, ${ }^{1,3,26,33}$ or total parenteral nutrition ${ }^{4,5,8}$ can be tried, especially if the patient is reluctant to undergo surgery or has concomitant life-limiting disease . Conservative treatment failed in $57.1 \%$ of the cases reported, ${ }^{25}$ and surgical treatment was curative in all. One late death resulting from bleeding was described. There are no clinical indicators to predict the failure of conservative therapy. Given the low mortality rate in idiopathic chylopericardium, initial treatment should include pericardiocentesis with a pericardiostomy tube, along with medium chain triglyceride diet. Failure of this therapy should prompt surgical intervention. The average time from the initiation of conservative therapy to the scheduling of surgical intervention has been 150 days on average, but the median was 12 days (ranging from 1 day to 1460 days) as reported in the literature in the past 10 years. This skewing is the result of a single case $\mathrm{c}^{28}$ in which the time from conservative to surgical treatment period was 4 years (1460 days). We concur with Wurnig and associates ${ }^{28}$ and suggest surgical intervention in all patients with hemodynamically significant effusions. In addition, recurrence after pericardiocentesis and failed conservative treatment should be indications for surgical management. Given that a continuing leakage of chyle can lead to serious metabolic, nutritional, and immunologic abnormalities, an average daily loss of chyle of $500 \mathrm{~mL}$ daily over a 5-day period should be an indication for surgical intervention. Almost all patients who had a recurrent chylous pericardial effusion in a 3-month period required surgical treatment. Therefore, recurrence should prompt evaluation for surgical intervention. Treatment of patients with secondary chylopericardium should be directed against the underlying cause. Surgery is indicated early in the course of tumorinduced chylous pericardial effusion and also after a traumatic event when the daily loss of chyle exceeds $1500 \mathrm{~mL}$ per day in an adult patient. ${ }^{37}$ Consideration to the use of radiotherapy and chemotherapy can be discussed if malignant disease is present in the absence of hemodynamic instability.

Surgical intervention may include thoracic duct ligation, which usually leads to collateral circulation regardless of the level of ligation. After ligation, pressures as high as 50 $\mathrm{mm} \mathrm{Hg}$ have been recorded in the pericardium. This was subsequently followed by a fall in the blood lipid level (from $>$ $500 \mathrm{mg} / \mathrm{dL}$ to $280 \mathrm{mg} / \mathrm{dL}$ ), gradually returning to normal within 16 days. ${ }^{38}$ To ensure the success of the surgical procedure, the thoracic duct should be ligated in the lower part of the thorax and a pericardial window should be created to allow adequate drainage and prevent complications such as constrictive pericarditis. ${ }^{28}$ Creation of a pericardial window without thoracic duct ligation is associated with recurrence in $50 \%$ of the cases, whereas it is rare after ligation ${ }^{39,40}$ and mostly occurs if duplication of the thoracic duct is present. ${ }^{41}$

The specific type of surgical procedure, VATS versus open thoracotomy, depends on the local expertise. Left or right thoracotomy may be used. Akamatsu and associates ${ }^{39}$ prefer left thoracotomy inasmuch as the thoracic duct has its main course in the left hemithorax, surgical time is shorter, and the likelihood of injury to the esophagus and descending aorta are lower. The right-sided approach allows easier access to the duct. The duct should be ligated near the diaphragm owing to the variation in its anatomy above that level, ${ }^{28}$ and mass ligation is recommended because of wide anatomic variations in that specific area above the diaphragm. ${ }^{29}$ Cases involving identification and clipping of 
the thoracic duct have been described, ${ }^{28,42,43}$ and VATS has been used ${ }^{28}$ with magnification allowing easier identification of mediastinal structures. The VATS procedure is being used increasingly and is associated with less postoperative pain and pulmonary dysfunction. ${ }^{44}$

\section{Conclusion}

Chylopericardium is a rare entity. Presentation may be acute, chronic, or even subclinical. Diagnosis always requires pericardiocentesis when the color of the fluid characteristics, triglyceride content, cytologic examination, and negative culture suggests the diagnosis. Patients should undergo chest computed tomography followed by lymphangioscintigraphy/lymphangiography to rule out secondary causes. Treatment of the underlying cause should always be the therapy of choice. Cases of idiopathic chylopericardium have been reported in which conservative therapy with follow-up may be successful. Conservative therapy should be performed in cases of idiopathic chylopericardium or if there is an untreatable underlying medical condition that shortens lifespan or surgical risks are considered too high. Open thoracotomy or VATS, when available, should be considered when conservative measures fail or there are no contraindications to surgery. Surgery should include thoracic duct mass ligation above the diaphragm with a pericardial window for subsequent drainage and prevention of complications such as constrictive pericardial disease.

\section{References}

1. Pitol R, Pederiva JR, Pasin F, Vitola D. Isolated chylopericardium after cardiac surgery. Arq Bras Cardiol. 2004;82:384-9.

2. Yater WM. Non-traumatic chylothorax and chylopericardium. Ann Intern Med. 1935;9:600.

3. Baratella MC, Montesello M, Marinato P. Images in cardiology. Idiopathic chylopericardium. Heart. 1998;80:376.

4. Sasaki A, Watanabe Y, Tokunaga C. Chylopericardium following mitral valve replacement. Jpn J Thorac Cardiovasc Surg. 2002;50:518-9.

5. Sharpe DA, Pullen MD, McGoldrick JP. A minimally invasive approach to chylopericardium after coronary artery surgery. Ann Thorac Surg. 1999;68:1062-3.

6. Gelsomino S, Morelli A, Porreca L, Morocutti G, Da Col P, Livi U. Video-assisted thoracoscopic surgery for primary chylopericardium after orthotopic heart transplantation. J Heart Lung Transplant. 2002; 21:701-5.

7. Mogulkoc N, Onal B, Okyay N, Gunel O, Bayindir U. Chylothorax, chylopericardium and lymphoedema-the presenting features of signet-ring cell carcinoma. Eur Respir J. 1999;13:1489-91.

8. Swelstad MR, Frumiento C, Garry-McCoy A, Agni R, Weigel TL. Chylotamponade: an unusual presentation of Gorham's syndrome. Ann Thorac Surg. 2003;75:1650-2.

9. Andrade Santiago J, Robles L, Casimiro C, Casado V, Ageitos A, Domine M, et al. Chylopericardium of neoplastic aetiology. Ann Oncol. 1998:9:1339-42.

10. Watanabe S, Kariatsumari K, Sakasegawa K, Imagama I, Yotsumoto G, Sakata R. Primary chylopericardium treated with video-assisted thoracoscopic surgery. Thorac Cardiovasc Surg. 2002;50:360-1.

11. Yokusoglu M, Savasoz BS, Baysan O, Erinc K, Gunay C, Isik E. Primary chylopericardium. Thorac Cardiovasc Surg. 2005;53:386-8.

12. Mahon NG, Nolke L, McCann H, Sugrue D, Hurley J. Isolated chylopericardium. Surgeon. 2003;1:236-8.
13. Sakata S, Yoshida I, Otani Y, Ishikawa S, Morishita Y. Thoracoscopic treatment of primary chylopericardium. Ann Thorac Surg. 2000;69: $1581-2$.

14. Wang CH, Yen TC, Ng KK, Lee CM, Hung MJ, Cherng WJ. Pedal $(99 \mathrm{~m}) \mathrm{Tc}$-sulfur colloid lymphoscintigraphy in primary isolated chylopericardium. Chest. 2000;117:598-601.

15. Sleilaty G, Rassi I, Alawi A, Jebara VA. Primary isolated chronic chylopericardium. Interact Cardiovasc Thorac Surg. 2002;1:86-7.

16. Mulrow CD. The medical review article: state of the science. Ann Intern Med. 1987; 106:485-8.

17. Chen CM, Ku PM, Lu YY, Fong Y, Huang TY. Secondary chylopericardium complicated with cardiac tamponade in a drug addict: a case report. J Intern Med Taiwan. 2004;15:214-8.

18. Chello M, Mastroroberto P, Cirillo F, Malta E. Primary chylopericardium in a heroin addict. Asian Cardiovasc Thorac Annals. 1998;6:235-6.

19. Scholten C, Staudacher M, Girsch W, Wolf G, Grimm M, Binder T, et al. A novel therapeutic strategy for the management of idiopathic chylopericardium and chylothorax. Surgery. 1998;123:369-70.

20. Nanjo S, Yamazaki J, Tsubuku M, Ohyama T, Ohtsuka T, Nakano H. Primary idiopathic chylopericardium: report of two cases. Ann Nucl Med. 2004;18:537-9.

21. Zisis C, Rontogianni D, Charalambous E, Bellenis I. Lymphangiomatous hamartoma: cause or bystander of the isolated chylopericardium? J Thorac Cardiovasc Surg. 2005;130:1201-2.

22. Mitsui K, Namiki K, Matsumoto H, Konno F, Yoshida R, Miura S. Thoracoscopic treatment for primary chylopericardium: report of a case. Surg Today. 2005;35:76-9.

23. Mehrotra S, Peeran NA, Bandyopadhyay A. Idiopathic chylopericardium: an unusual cause of cardiac tamponade. Tex Heart Inst J. 2006; 33:249-52.

24. Cho BC, Kang SM, Lee SC, Moon JG, Lee DH, Lim SH. Primary idiopathic chylopericardium associated with cervicomediastinal cystic hygroma. Yonsei Med J. 2005;46:439-44.

25. Yoshioka H, Shigemitsu K, Takeuchi M, Mori S, Imaizumi M, Ueda Y. Salmonella pericarditis in a patient with primary idiopathic chylopericardium. Jpn J Thorac Cardiovasc Surg. 2003;51:16-7.

26. Chen FC, Huang JL, Lin WY, Ting CT. Pedal Tc-99m phytate lymphoscintigraphy in primary chylopericardium. Int J Cardiol. 2003;90:341-3.

27. Ossiani MH, McCauley RG, Patel HT. Primary idiopathic chylopericardium. Pediatr Radiol. 2003;33:357-9.

28. Wurnig PN, Hollaus PH, Ohtsuka T, Flege JB, Wolf RK. Thoracoscopic direct clipping of the thoracic duct for chylopericardium and chylothorax. Ann Thorac Surg. 2000;70:1662-5.

29. Furrer M, Hopf M, Ris HB. Isolated primary chylopericardium: treatment by thoracoscopic thoracic duct ligation and pericardial fenestration [see comment]. J Thorac Cardiovasc Surg. 1996;112:1120-1.

30. Liberman M, Klopfenstein JJ. Chylopericardial tamponade. Interact Cardiovasc Thorac Surg. 2006;5:249-50.

31. Svedjeholm R, Jansson K, Olin C. Primary idiopathic chylopericardium-a case report and review of the literature. Eur J Cardiothoracic Surg. 1997;11:387-90.

32. Pop D, Benizri EI, Venissac N, Leo F, Padovani B, Mouroux J. Mediastinal cystic lymphangioma: is resection always necessary? Thorac Cardiovasc Surg. 2005;53:243-4.

33. Veroux P, Veroux M, Bonanno MG, Tumminelli MG, Baggio E, Petrillo G. Long-term success of endovascular treatment of benign superior vena cava occlusion with chylothorax and chylopericardium. Eur Radiol. 2002;12(Suppl 3):S181-4.

34. Wieshammer S, Gorissen B, Kiefer T. Chylopericardium following pulmonary tuberculosis. Deutsch Med Wochenschr. 2006;131:1860-2.

35. Coplu L, Emri S, Selcuk ZT, Kalyoncu F, Balkanci F, Sahin AA, et al. Life threatening chylous pleural and pericardial effusion in a patient with Behcet's syndrome. Thorax. 1992;47:64-5.

36. Backer CL. Thoracic duct ligation for chylopericardium [comment]. J Thorac Cardiovasc Surg. 1998;115:734.

37. Selle JG, Snyder WH 3rd, Schreiber JT. Chylothorax: indications for surgery. Ann Surg. 1973;177:245-9.

38. Ross JK. A review of the surgery of the thoracic duct. Thorax. 1961;16: 12-21.

39. Akamatsu H, Amano J, Sakamoto T, Suzuki A. Primary chylopericardium. Ann Thorac Surg. 1994;58:262-6. 
40. Dunn RP. Primary chylopericardium: a review of the literature and an illustrated case. Am Heart J. 1975;89:369-77.

41. Kannagi T, Osakada G, Wakabayashi A, Kawai C, Matsuda M, Miki S. Primary chylopericardium. Chest. 1982;81:105-8.

42. Kent RB 3rd, Pinson TW. Thoracoscopic ligation of the thoracic duct. Surg Endosc. 1993;7:52-3.
43. Crosthwaite GL, Joypaul BV, Cuschieri A. Thoracoscopic management of thoracic duct injury. J R Coll Surg Edinb. 1995;40:303-4.

44. Kirby TJ, Mack MJ, Landreneau RJ, Rice TW. Lobectomy-videoassisted thoracic surgery versus muscle-sparing thoracotomy. A randomized trial. J Thorac Cardiovasc Surg. 1995;109:997-1001; discussion 1002.

Send us your new address at least six weeks ahead

Don't miss a single issue of the journal! To ensure prompt service when you change your address, please photocopy and complete the form below.

Please send your change of address notification at least six weeks before your move to ensure continued service. We regret we cannot guarantee replacement of issues missed due to late notification.

\section{JOURNAL TITLE:}

Fill in the title of the journal here.

\section{OLD ADDRESS:}

Affix the address label from a recent issue of the journal here.

\section{NEW ADDRESS:}

Clearly print your new address here.

Name

Address

City/State/ZIP
COPY AND MAIL THIS FORM TO:

Elsevier Inc.

Subscription Customer Service

6277 Sea Harbor Dr

Orlando, FL 32887
OR FAX TO:

407-363-9661

OR E-mail:

elspcs@elsevier.com
OR PHONE:

800-654-2452

Outside the U.S., call

407-345-4000 